\title{
Origin of Increased Sulfate in Groundwater at the ETF Disposal Site
}

\author{
E. C. Thornton
}

September 1997

Prepared for

the U.S. Department of Energy under Contract DE-AC06-76RLO 1830

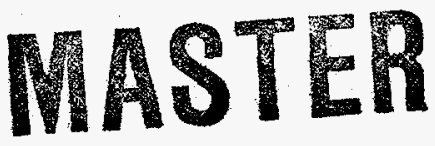

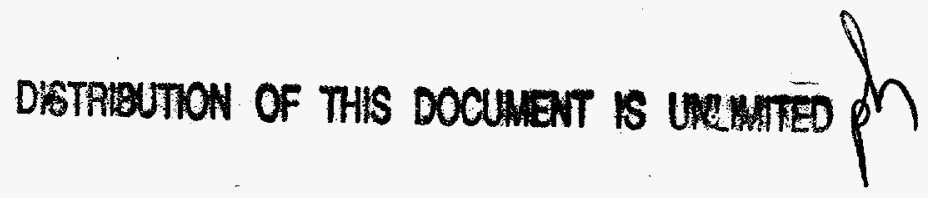

Pacific Northwest National Laboratory

Richland, Washington 99352 


\section{DISCLAIMER}

This report was prepared as an account of work sponsored by an agency of the United States Government. Neither the United States Government nor any agency thereof, nor any of their employees, makes any warranty, express or implied, or assumes any legal liability or responsibility for the accuracy, completeness, or usefulness of any information, apparatus, product, or process disclosed, or represents that its use would not infringe privately owned rights. Reference herein to any specific commercial product, process, or service by trade name, trademark, manufacturer, or otherwise does not necessarily constitute or imply its endorsement, recommendation, or favoring by the United States Government or any agency thereof. The views and opinions of authors expressed herein do not necessarily state or reflect those of the United States Government or any agency thereof. 


\section{DISCLAMIER}

Portions of this docoment may be illegible in electronic image products. Images are produced from the best availabie original document. 


\section{Summary}

Treated effluent being discharged to the vadose zone from the C-018H Effluent Treatment Facility (ETF) at the Hanford Site has infiltrated vertically to the unconfined aquifer, as indicated by increasing tritium activity levels in the groundwater. Well 699-48-77A, in particular, exhibits increased levels of tritium and also sulfate in the groundwater.

The origin of increased sulfate levels in the groundwater is attributed to the dissolution of gypsum as the effluent flows through the vadose zone. This is supported by the observation that sulfate was found to be present in soils collected from the vadose zone at an average value of about $10.6 \mathrm{ppm}$. The maximum observed sulfate concentration of $190 \mathrm{mg} / \mathrm{L}$ from well $699-48-77 \mathrm{~A}$ was observed on August 6,1996 , and is less than the maximum value of $879 \mathrm{mg} / \mathrm{L}$ that potentially could be achieved if water in the vadose zone was to attain saturation with respect to gypsum and calcite. It is suggested that infiltration rates were high enough that the effluent did not completely equilibrate with gypsum in the vadose zone, and thus, sulfate levels remained below gypsum saturation levels. Sulfate levels appear to be dropping, which may be attributed to the completion of the dissolution of the bulk of gypsum present along the vadose zone flow path traversed by the effluent.

Geochemical modeling was undertaken to evaluate the influence of effluent chemistry on sulfate concentration levels in the presence of excess calcite and gypsum. In general, the effect is fairly minor for dilute solutions, but becomes more significant for concentrated solutions. 


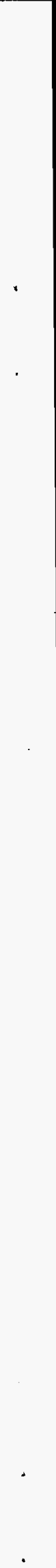




\section{Acknowledgments}

The author wishes to thank D. B. Barnett, D. L. Flyckt, and P. C. Mohondro for their interest and support during the performance of this study. 



\section{Contents}

Summary $\ldots \ldots \ldots \ldots \ldots \ldots \ldots \ldots \ldots \ldots \ldots \ldots \ldots \ldots \ldots \ldots \ldots \ldots \ldots$ iii

Acknowledgments $\ldots \ldots \ldots \ldots \ldots \ldots \ldots \ldots \ldots \ldots \ldots \ldots \ldots \ldots \ldots \ldots \ldots$

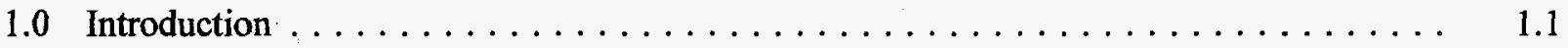

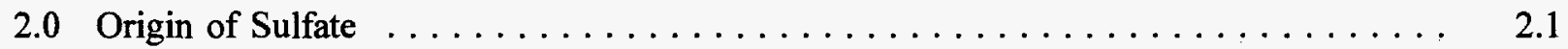

2.1 Identification of Breakthrough of the Vadose Zone Wetting Front . . . . . . . 2.1

2.2 Changes in Groundwater Chemistry . . . . . . . . . . . . . 2.1

2.3 Soil Chemistry and Leaching Studies $\ldots \ldots \ldots \ldots \ldots \ldots \ldots \ldots \ldots$

3.0 Variation in Aqueous Sulfate Concentration during Mineral Dissolution as a Function of Initial Effluent Composition $\ldots \ldots \ldots \ldots \ldots \ldots \ldots \ldots \ldots \ldots \ldots \ldots \ldots \ldots \ldots \ldots$

4.0 Conclusions $\ldots \ldots \ldots \ldots \ldots \ldots \ldots \ldots \ldots \ldots \ldots \ldots \ldots \ldots \ldots \ldots \ldots \ldots \ldots$

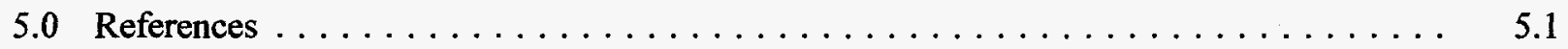

Appendix - Soil Column Leach Test Data $\ldots \ldots \ldots \ldots \ldots \ldots \ldots \ldots \ldots \ldots \ldots \ldots$ 


\section{Figures}

2.1 Variation in Groundwater Chemistry for Samples from Well 699-48-77A $\ldots \ldots \ldots$

2.2 Variation in Sulfate Concentration Versus Number of Pore Volumes of Effluent

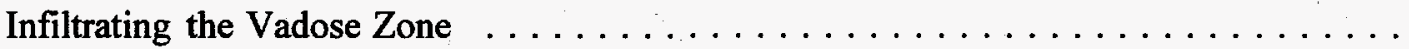

\section{Tables}

2.1 Variation of Selected Constituents and Specific Conductance in ETF Groundwater Monitoring Well Samples Indicative of Breakthrough $\ldots \ldots \ldots \ldots \ldots \ldots$

2.2 Groundwater Chemical Analyses for Samples from Well 699-48-77A . . . . . . . 2.3

2.3 Groundwater Chemical Analyses for Samples Collected on August 6, $1996 \ldots \ldots$. . . . 2.4

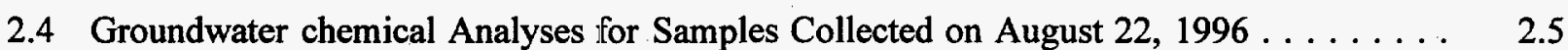

2.5 Summary of Vadose Zone Sulfate Concentrations Based on Soil Analysis and Leach Test Result . . . . . . . . . . . . . . . . . . . . . .

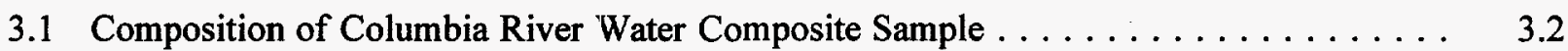

3.2 Solubility of Gypsum and Calcite in Pure Water versus Columbia River Water $\ldots \ldots .2$

3.3 Solubility of Gypsum and Calcite in Water as a Function of Initial

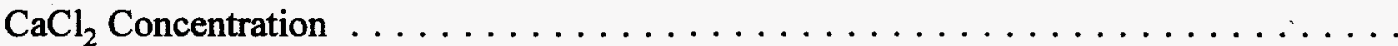




\subsection{Introduction}

Treated effluent is presently being discharged to the vadose zone from the C-018H Effluent Treatment Facility (ETF) at the Hanford Site under an operating permit. The effluent being released has essentially no dissolved content, but contains significant tritium. Release of effluent began on November 12,1995 . It is estimated that average tritium levels in the effluent will be about $6,300,000 \mathrm{pCi} / \mathrm{L}$ (Davis et al. 1995).

Monitoring in wells around the disposal site indicates breakthrough of the treated waste water as demonstrated by increasing tritium activity levels in the groundwater. Well 699-48-77A, in particular, exhibits increased levels of tritium and also sulfate in the groundwater. The primary objective of this report is to identify the origin of the sulfate and to assess, if possible, the potential for further increases in the concentration level of sulfate in the aquifer and the maximum possible level of sulfate that could be attained.

Potential variation in aqueous sulfate concentration levels that could result from variation in effluent composition is also evaluated. This analysis assumes that the effluent achieves equilibrium with gypsum in the vadose zone. This information is presented as a basis for predicting the potential for decreasing sulfate levels by controlling or modifying effluent composition. 


\subsection{Origin of Sulfate}

\subsection{Identification of Breakthrough of the Vadose Zone Wetting Front}

Water released from the ETF will infiltrate the vadose zone and move vertically downwards until it reaches the groundwater. Initial breakthrough of the wetting front can be determined by monitoring the concentration of constituents in groundwater samples that reflect the introduction of vadose zone water. These would be constituents originally present in the waste water or acquired by dissolution of minerals or salts in the vadose zone.

Table 2.1 summarizes the levels of chloride, sulfate, tritium, and specific conductance in selected groundwater samples collected from wells 699-48-77A, 699-48-77C, and 699-48-77D. Chloride and sulfate are constituents that are a measure of dissolution processes occurring in the vadose zone, while specific conductance is a measure of the total amount of dissolved material present in water entering the groundwater from the vadose zone. Tritium may be regarded as a chemically conservative constituent (i.e., nonreactive and nonsorbing) introduced with the treated effluent. This constituent is particularly useful in identifying breakthrough of effluent into the unconfined aquifer owing to much higher activity levels in the treated effluent compared to groundwater in the area.

Tritium activity levels in groundwater samples from well 699-48-77A indicate that breakthrough of effluent to the unconfined aquifer occurred by mid-July 1996 (Table 2.1). This conclusion is further supported by increased levels of sulfate observed in mid-July and increased chloride concentration and specific conductance values observed in samples collected in August. Breakthrough has also occurred in well $699-48-77 \mathrm{C}$, based on the tritium activity of a sample collected on 8/22/96. No significant increase in the levels of tritium has yet occurred in samples collected from well 699-48-77D, although sulfate levels appear to have increased recently.

\subsection{Changes in Groundwater Chemistry}

Chemical analyses for selected groundwater samples collected from wells 699-48-77A, 699-48-77C, and 699-48-77D are presented in Tables 2.2, 2.3, and 2.4. This information provides a basis for describing the chemistry of water that has traversed the vadose zone and for identifying major water/soil interaction processes responsible for controlling vadose zone water chemistry. In particular, changes in the chemistry of water samples collected from well 699-48-77A illustrates a transition from normal water chemistry of the area to a chemistry that reflects that of water entering the aquifer from the vadose zone.

The increase in specific conductance observed in samples collected from well 699-48-77A can be attributed to dissolution of minerals during infiltration of water through the vadose zone (Figure 2.1). For example, significant increases of chloride from about 5 to greater than $90 \mathrm{mg} / \mathrm{L}$ probably reflects the dissolution of minor amounts of salts in the vadose zone. Likewise, calcium increases from about $30 \mathrm{mg} / \mathrm{L}$ to over $90 \mathrm{mg} / \mathrm{L}$, magnesium increases from $12 \mathrm{mg} / \mathrm{L}$ to about $40 \mathrm{mg} / \mathrm{L}$, and sulfate increases from about $23 \mathrm{mg} / \mathrm{L}$ to about $190 \mathrm{mg} / \mathrm{L}$. The joint increase in calcium and sulfate may be attributed to 
Table 2.1. Variation of Selected Constituents and Specific Conductance in ETF Groundwater Monitoring Well Samples Indicative of Breakthrough

\begin{tabular}{|c|c|c|c|c|c|}
\hline Well & Collect Date & Chloride, mg/l & Sulfate, $\mathrm{mg} / \mathrm{l}$ & Tritium, pCi/l & $\begin{array}{l}\text { Sp. Cond., } \\
\text { umho/cm }\end{array}$ \\
\hline $699-48-77 \mathrm{~A}$ & $2 / 4 / 95$ & 4 & 22 & 343 & 285 \\
\hline$"$ & $4 / 17 / 95$ & 4 & 22 & 300 & 280 \\
\hline$"$ & $7 / 12 / 95$ & 4 & 21 & 87 & 330 \\
\hline$"$ & $10 / 24 / 95$ & 4 & 21 & 149 & -- \\
\hline$"$ & $1 / 15 / 96$ & -- & 23 & 260 & -- \\
\hline$"$ & $4 / 3 / 96$ & -- & 21 & 300 & -- \\
\hline$"$ & $7 / 15 / 96$ & -- & 158 & 74000 & -- \\
\hline$"$ & $8 / 6 / 96$ & 97 & 192 & 210000 & 850 \\
\hline$"$ & $8 / 22 / 96$ & 93 & 177 & 270000 & 925 \\
\hline $699-48-77 \mathrm{C}$ & $2 / 4 / 95$ & 5 & 19 & 609 & 294 \\
\hline$"$ & $4 / 17 / 95$ & 5 & 19 & 543 & 283 \\
\hline$"$ & $7 / 12 / 95$ & 5 & 20 & 231 & 291 \\
\hline$"$ & $10 / 24 / 95$ & 5 & 20 & 336 & -- \\
\hline$"$ & $1 / 15 / 96$ & - & 19 & 390 & -- \\
\hline$"$ & $4 / 3 / 96$ & -- & 18 & 300 & -- \\
\hline$"$ & $7 / 15 / 96$ & -- & 17 & 410 & -- \\
\hline$"$ & $8 / 6 / 96$ & 6 & 19 & 390 & 293 \\
\hline$"$ & $8 / 22 / 96$ & 6 & 19 & 3000 & 296 \\
\hline 699-48-77D & $2 / 4 / 95$ & 6 & 23 & 343 & 301 \\
\hline$"$ & $4 / 17 / 95$ & 7 & 23 & 305 & 294 \\
\hline$"$ & $7 / 12 / 95$ & 7 & 22 & 102 & 303 \\
\hline$"$ & $10 / 24 / 95$ & 7 & 23 & 58 & -- \\
\hline$"$ & $1 / 15 / 96$ & - & 24 & 240 & -- \\
\hline$"$ & $4 / 3 / 96$ & -- & 32 & 300 & -- \\
\hline$"$ & $7 / 15 / 96$ & -- & 72 & 400 & -- \\
\hline$"$ & $8 / 6 / 96$ & 23 & 105 & 380 & 444 \\
\hline$"$ & $8 / 22 / 96$ & 17 & 66 & 410 & 427 \\
\hline
\end{tabular}


Table 2.2. Groundwater Chemical Analyses for Samples from Well 699-48-77A

\begin{tabular}{|c|c|c|c|c|c|c|c|c|}
\hline Site Identification & $699-48-77 A$ & $Q$ & $699-48-77 A$ & $\mathrm{Q}$ & $699-48-77 A$ & $Q$ & $699-48-77 A$ & $\mathrm{Q}$ \\
\hline Sample type & water & & water & & water & & water & \\
\hline Date & $06 / 19 / 92$ & & $05 / 17 / 93$ & & $07 / 12 / 95$ & & $04 / 03 / 96$ & \\
\hline HEIS Sample No. & B06W97 & & B08JD2 & & B0G4V6 & & B0HKW1 & \\
\hline Filtered/Unfiltered & uf & & uf & & uf & & uf & \\
\hline \multicolumn{9}{|l|}{ Quality control sample } \\
\hline \multicolumn{9}{|l|}{ Aluminum (ug/l) } \\
\hline \multicolumn{9}{|l|}{ Barium (ug/l) } \\
\hline Calcium (ug/l) & 33,000 & & 29,000 & & 30,200 & & & \\
\hline \multicolumn{9}{|l|}{ Chromium (ug/l) } \\
\hline \multicolumn{9}{|l|}{ Iron (ug/l) } \\
\hline Magnesium (ug/l) & 12,000 & & $11,000^{\circ}$ & & 11,700 & & & \\
\hline \multicolumn{9}{|l|}{ Nickel (ug/l) } \\
\hline Potassium (ug/l) & 3,300 & & 3,000 & & 2,400 & & & \\
\hline Sodium (ug/l) & 17,000 & & 11,000 & & 9,330 & & & \\
\hline \multicolumn{9}{|l|}{ Vanadium (ug/l) } \\
\hline \multicolumn{9}{|l|}{ Bromide (mg/l) } \\
\hline Chloride (mg/l) & 6.6 & & 5.3 & & 4 & & & \\
\hline \multicolumn{9}{|l|}{ Fluoride $(\mathrm{mg} / \mathrm{l})$} \\
\hline \multicolumn{9}{|l|}{ Nitrite $(\mathrm{mg} / \mathrm{l})$} \\
\hline Nitrate $(\mathrm{mg} / \mathrm{l})$ & 28 & & 21 & & & & & \\
\hline \multicolumn{9}{|l|}{ Phosphate (mg/l) } \\
\hline Sulfate $(\mathrm{mg} / \mathrm{l})$ & 25 & & 23 & & 21 & & 21 & \\
\hline TDS (mg/l) & & & & & 190 & & 180 & \\
\hline pH & 7.71 & & 7.76 & & 7.97 & & 7.99 & \\
\hline sp. cond. $(\mathrm{uS} / \mathrm{cm})$ & & & 290 & & 330 & & & \\
\hline alk (mg/l CaCO3) & & & & & 103 & & 93 & \\
\hline $\mathrm{H}-3(\mathrm{pCi} / \mathrm{l})$ & 64 & & 89 & & 87 & & 300 & \\
\hline \multicolumn{9}{|l|}{ alpha screen $(\mathrm{pCi} / \mathrm{ml})$} \\
\hline beta screen $(p C i / 1)$ & & & & & & & & \\
\hline
\end{tabular}


Table 2.3. Groundwater Chemical Analyses for Samples Collected on August 6, 1996

\begin{tabular}{|c|c|c|c|c|c|c|c|c|}
\hline Site Identification & $699-48-77 A$ & $\mathbf{Q}$ & $699-48-77 A$ & $\mathrm{Q}$ & $699-48-77 \mathrm{C}$ & $\mathrm{Q}$ & $699-48-77 \mathrm{D}$ & $\mathrm{Q}$ \\
\hline Sample type & water & & water & & water & & water & \\
\hline Date & $08 / 06 / 96$ & & $08 / 06 / 96$ & & $08 / 06 / 96$ & & 08/06/96 & \\
\hline HEIS Sample No. & BOJ667 & & B0J672 & & BOJ709 & & BOJ715 & \\
\hline Filtered/Unfiltered & uf & & uf & & uf & & uf & \\
\hline Quality control sample & & & dup & & & & & \\
\hline Aluminum (ug/l) & 43 & $\mathrm{U}$ & 43 & $\mathrm{U}$ & & & 43 & $\mathbf{U}$ \\
\hline Barium (ug/l) & 56 & & 61 & & & & 28 & \\
\hline Calcium (ug/l) & 92,000 & B & 99,500 & B & & & 47,000 & B \\
\hline Chromium (ug/l) & 25 & & 21 & & & & 8 & $\mathrm{U}$ \\
\hline Iron (ug/l) & 141 & & 141 & B & & & 17. & B \\
\hline Magnesium (ug/l) & 38,300 & B & 41,100 & B & & & 18,600 & B \\
\hline Nickel (ug/l) & 20 & & 22 & & & & 16 & $\mathrm{U}$ \\
\hline Potassium (ug/l) & 4,560 & B & 5,840 & B & & & 4,180 & B \\
\hline Sodium (ug/l) & 12,800 & B & 13,800 & B & & & 9,880 & B \\
\hline Vanadium (ug/l) & 23 & & 26 & & & & 28 & \\
\hline Bromide (mg/) & 1.58 & & 1.58 & & 0.00 & $\mathbf{U}$ & 0.00 & $\mathrm{U}$ \\
\hline Chloride (mg/) & 97.0 & & 99.9 & & 6.14 & & 22.8 & \\
\hline Fluoride (mg/l) & 0.356 & & 0.369 & & 0.326 & & 0.285 & \\
\hline Nitrite (mg/) & 0.00 & $\mathrm{U}$ & 0.00 & $\mathrm{U}$ & 0.00 & $\mathrm{U}$ & 0.00 & $\mathbf{U}$ \\
\hline Nitrate $(\mathrm{mg} / \mathrm{l})$ & 4.29 & & 4.45 & & 5.40 & & 1.56 & \\
\hline Phosphate (mg/l) & 0.00 & $\mathrm{U}$ & 0.00 & $\mathrm{U}$ & 0.00 & $\mathrm{U}$ & 0.00 & $\mathbf{U}$ \\
\hline Sulfate $(\mathrm{mg} / \mathrm{l})$ & 192 & & 194 & & 19.2 & & 105 & \\
\hline TDS (mg/l) & 532 & & 561 & & 149 & & 308 & \\
\hline $\mathrm{pH}$ & 7.81 & & 7.77 & & 7.93 & & 8.06 & \\
\hline sp. cond. (uS/cm) & 850 & & 846 & & 293 & & 444 & \\
\hline alk (mg/l CaCO3) & 45.7 & & 84.0 & & 88.2 & & 106.4 & \\
\hline $\mathrm{H}-3(\mathrm{pCi} / \mathrm{l})$ & 210,000 & & 210,000 & & 390 & & 380 & $U$ \\
\hline alpha screen (pCi/ml) & ND & & ND & & 0.5 & & $\mathrm{ND}$ & \\
\hline beta screen $(\mathrm{pCi} / \mathrm{l})$ & ND & & ND & & ND & & ND & \\
\hline
\end{tabular}


Table 2.4. Groundwater Chemical Analyses for Samples Collected on August 22, 1996

\begin{tabular}{|c|c|c|c|c|c|c|c|c|}
\hline Site Identification & $699-48-77 A$ & Q & $699-48-77 \mathrm{C}$ & $Q$ & $699-48-77 \mathrm{C}$ & $\mathbf{Q}$ & 699-48-77D & $Q$ \\
\hline Sample type & water & & water & & water & & water & \\
\hline Date & $08 / 22 / 96$ & & $08 / 22 / 96$ & & $08 / 22 / 96$ & & $08 / 22 / 96$ & \\
\hline HEIS Sample No. & BOJ744 & & B0J748 & & BOJ752 & & BOJ753 & \\
\hline Filtered/Unfiltered & uf & & uf & & uf & & uf & \\
\hline Quality control sample & & & & & dup & & & \\
\hline \multicolumn{9}{|l|}{ Aluminum (ug/l) } \\
\hline \multicolumn{9}{|l|}{ Barium (ug/l) } \\
\hline \multicolumn{9}{|l|}{ Calcium (ug/l) } \\
\hline \multicolumn{9}{|l|}{ Chromium (ug/l) } \\
\hline \multicolumn{9}{|l|}{ Iron $(u g / l)$} \\
\hline \multicolumn{9}{|l|}{ Magnesium (ug/l) } \\
\hline \multicolumn{9}{|l|}{ Nickel (ug/l) } \\
\hline \multicolumn{9}{|l|}{ Potassium (ug/l) } \\
\hline \multicolumn{9}{|l|}{ Sodium (ug/l) } \\
\hline \multicolumn{9}{|l|}{ Vanadium (ug/l) } \\
\hline Bromide (mg/l) & 1.295 & $\mathrm{~J}$ & 0.03 & $<$ & 0.03 & $<$ & 0.911 & $\mathrm{~J}$ \\
\hline Chloride (mg/) & 93.0 & & 5.627 & & 6.061 & & 16.85 & \\
\hline Fluoride (mg/l) & 0.279 & & 0.267 & & 0.276 & & 0.252 & \\
\hline Nitrate (mg/l) & 3.999 & & 5.282 & & 6.344 & & 1.256 & \\
\hline Nitrite (mg/l) & 0.02 & $<$ & 0.02 & $<$ & 0.02 & $<$ & 0.02 & $<$ \\
\hline Phosphate (mg/l) & 0.04 & $<$ & 0.04 & $<$ & 0.04 & $<$ & 0.04 & $<$ \\
\hline Sulfate (mg/l) & 177.2 & & 18.53 & & 18.60 & & 65.64 & \\
\hline TDS (mg/l) & 654 & & 260 & & 250 & & 301 & \\
\hline $\mathrm{pH}$ & 7.72 & & 7.84 & & 8.04 & & 7.32 & \\
\hline sp. cond. $(\mathrm{uS} / \mathrm{cm})$ & 925 & & 290 & & 296 & & 427 & \\
\hline \multicolumn{9}{|l|}{ alk (mg/l $\mathrm{CaCO} 3)$} \\
\hline $\mathrm{H}-3(\mathrm{pCi} / 1)$ & 270,000 & & 3,000 & & 180 & & 410 & \\
\hline sample screen $(\mathrm{pCi} / \mathrm{ml})$ & ND & & ND & & ND & & $\mathrm{ND}$ & \\
\hline
\end{tabular}




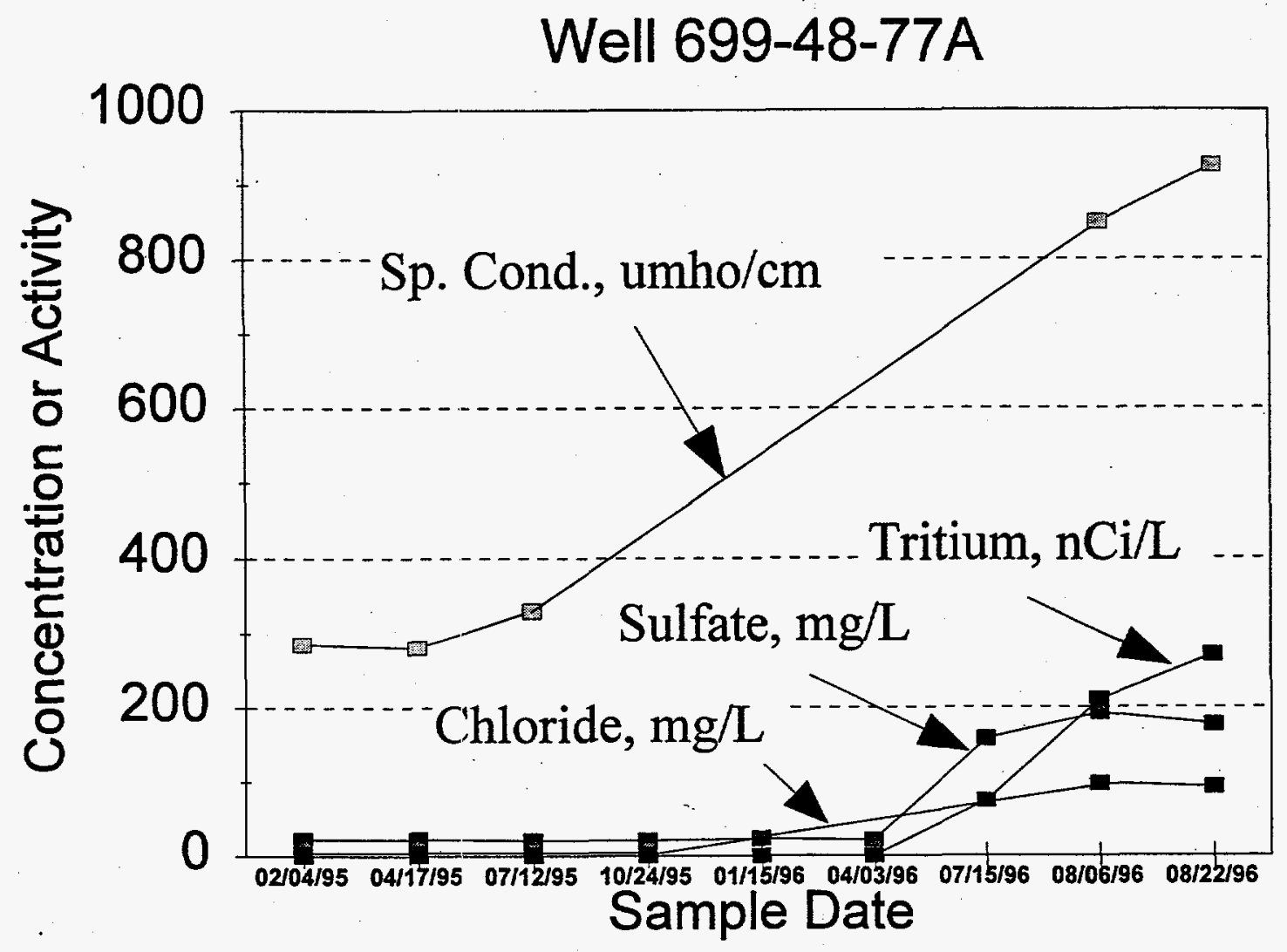

Figure 2.1. Variation in Groundwater Chemistry for Samples from Well 699-48-77A

dissolution of gypsum, $\mathrm{CaSO}_{4} \cdot 2 \mathrm{H}_{2} \mathrm{O}$, in the vadose zone. Increases in both calcium and magnesium may be due to the dissolution of a magnesium-rich calcite, $\mathrm{CaCO}_{3}$, in the vadose zone.

The hypothesis that dissolution of calcite and gypsum is an important control on water chemistry in the vadose zone may be tested by considering equilibria in the calcite-gypsum-water system (Garrels and Christ 1965; Freeze and Cherry 1979). In particular, the water should be saturated with respect to these minerals if they are present in significant quantities in the vadose zone, and the fluid residence time is sufficiently long for equilibrium conditions to be approached. This approach was utilized by employing the chemical analysis of sample B0J672 (Table 2.3), collected from well 699-48-77A on August 6, 1996. Note that for this sample,

$$
\begin{aligned}
& \mathrm{Ca}=99.5 \mathrm{mg} / \mathrm{L} \\
& \mathrm{SO}_{4}=194 \mathrm{mg} / \mathrm{L} \\
& \mathrm{pH}=7.77 \\
& \text { alkalinity }=84 \mathrm{mg} / \mathrm{L} \mathrm{CaCO}_{3} \\
& \text { ionic strength }=0.015 .
\end{aligned}
$$

From this information, it is possible to calculate saturation indices for the water sample relative to gypsum and calcite and thus assess whether the sample is undersaturated, saturated, or supersaturated 
with respect to these minerals. Performance of these calculations indicates that the water is slightly supersaturated with respect to calcite (saturation index $=1.69$ ), but undersaturated with gypsum (saturation index $=0.082$ ). It is concluded that calcium, alkalinity, and $\mathrm{pH}$ values are probably controlled by equilibria between vadose zone water and calcite, which is consistent with the ubiquitous presence of minor amounts of calcite in the vadose zone. It is further concluded that dissolution of gypsum is the probable source of sulfate in the water sample. The observation that the water sample is undersaturated with respect to gypsum suggests that gypsum is not present in sufficient quantities in the vadose zone to achieve saturation in the aqueous phase.

\subsection{Soil Chemistry and Leaching Studies}

Further insight into the transport of sulfate from the vadose zone to the aquifer can be obtained by considering information associated with soil analysis and soil leaching studies performed during characterization of the $\mathrm{C}-\mathrm{018H}$ disposal site (Reidel and Thornton 1993). In particular, data generated in the course of that work should indicate if sulfate is present in the vadose zone in sufficient quantities to account for the observed increases in sulfate levels in the groundwater.

Soil chemical data for samples collected in the vadose zone were below the limits of detection for sulfate (20 ppm) for all samples, except for a reported value of $37 \mathrm{ppm}$ for a sample collected at a depth of 29.7 to $30.7 \mathrm{ft}$ (Table 2.5). This interval was described in geological borehole logs as a zone containing calcrete, which generally contains calcite and gypsum. The analysis of the soil sample also indicated a concentration of $20,000 \mathrm{ppm}$ calcium (Reidel and Thornton 1993). Calcium concentrations of other soil samples analyzed ranged from 2,300 to $5,700 \mathrm{ppm}$. The interval from 23 to $65 \mathrm{ft}$ was described as a silty sandy pedogenic carbonate associated with the Plio-Pleistocene unit and early Palouse soil. This is overlain by sand and gravel of the Hanford formation. The interval below $65 \mathrm{ft}$, and the remainder of the vadose and saturated zones, is dominated by the gravel sequence of the Ringold Formation.

Soil column leach tests were also performed during the $\mathrm{C}-018 \mathrm{H}$ disposal site characterization study (Reidel and Thornton 1993). This work was conducted to determine if constituents in the vadose zone might be mobilized by infiltration of the treated effluent. Data from the tests can be utilized to determine the total amount of leachable sulfate associated with soil samples. The approach for doing this is presented in the Appendix and the resulting leachable sulfate soil concentrations are presented in Table 2.5 .

The data presented in Table 2.5 indicates that sulfate is present at low levels in the vadose zone, reaching a highest concentration of $37 \mathrm{ppm}$ in the interval from 29.7 to $30.7 \mathrm{ft}$ (analysis B01RG2). Although the data presented in Table 2.5 do not cover the entire vadose zone, the data provide information regarding sulfate levels in the Plio-Pleistocene Unit. It is likely that the highest abundances of gypsum are associated with this unit. An average value of about $10.6 \mathrm{ppm}$ for sulfate is obtained by considering the results of the leach tests and the $37 \mathrm{ppm}$ value for soil analysis B01RG2. 
Table 2.5. Summary of Vadose Zone Sulfate Concentrations Based on Soil Analysis and Leach Test Result

\begin{tabular}{|c|c|c||}
\hline Sample Depth, $\mathrm{ft}$ & $\begin{array}{c}\text { Soil Analysis or Leach } \\
\text { Test Result }\end{array}$ & $\begin{array}{c}\text { Soil } \mathrm{SO}_{4} \text { Concentration, } \\
\mathrm{ppm}\end{array}$ \\
\hline \hline 0.5 to 1.0 & Leach Test 2-1185 & 12.9 \\
\hline 1.5 to 2.0 & Leach Test 2-1186 & 5.9 \\
\hline 1.5 to 2.5 & Soil Analysis B01RG0 & $<20$ \\
\hline 26.0 to 26.5 & Leach Test 2-1188 & 8.5 \\
\hline 26.5 to 27.5 & Soil Analysis B01RG1 & $<20$ \\
\hline 29.7 to 30.7 & Soil Analysis B01RG2 & 37 \\
\hline 34.8 to 35.3 & Leach Test 2-1190 & 4.3 \\
\hline 43.1 to 43.6 & Leach Test 2-1192 & 11.7 \\
\hline 57.2 to 57.7 & Leach Test 2-1194 & 6.5 \\
\hline 57.7 to 58.2 & Leach Test 2-1195 & 4.8 \\
\hline 68.0 to 68.5 & Leach Test 2-1433 & 3.4 \\
\hline 68.5 to 70.0 & Soil Analysis B01RG3 & $<20$ \\
\hline 68.5 to 70.0 & Soil Analysis B01RG4 & $<20$ \\
\hline 84.7 to 86.2 & Soil Analysis B01RG7 & $<20$ \\
\hline 229.5 to 231.5 & Soil Analysis B01RG8 & $<20$ \\
\hline
\end{tabular}

A relationship of predicted sulfate levels of water in the vadose zone versus number of pore volumes flushed through the vadose zone can be developed by considering the properties of the soil and the average sulfate value presented above. If we assume that the soil in the vadose zone contains $10.6 \mathrm{ppm}$ sulfate and has a porosity of $33 \%$, a maximum aqueous concentration of $58.1 \mathrm{mg} / \mathrm{L}$ of sulfate could be attained if it were all dissolved in one pore volume of water. This concentration would be twice as high $(116.2 \mathrm{mg} / \mathrm{L})$ if we assume all sulfate was dissolved in $1 / 2$ pore volume of water or only half as high $(29 \mathrm{mg} / \mathrm{L})$ if it were dissolved in 2 pore volumes of water. The relationship between potential sulfate concentrations of vadose zone water versus number of pore volumes is presented in Figure 2.2. This diagram illustrates that the observed groundwater concentration of about $190 \mathrm{mg} / \mathrm{L}$ sulfate could be attained if 0.3 pore volumes of water traversing the vadose zone dissolved essentially all of the leachable sulfate present. 


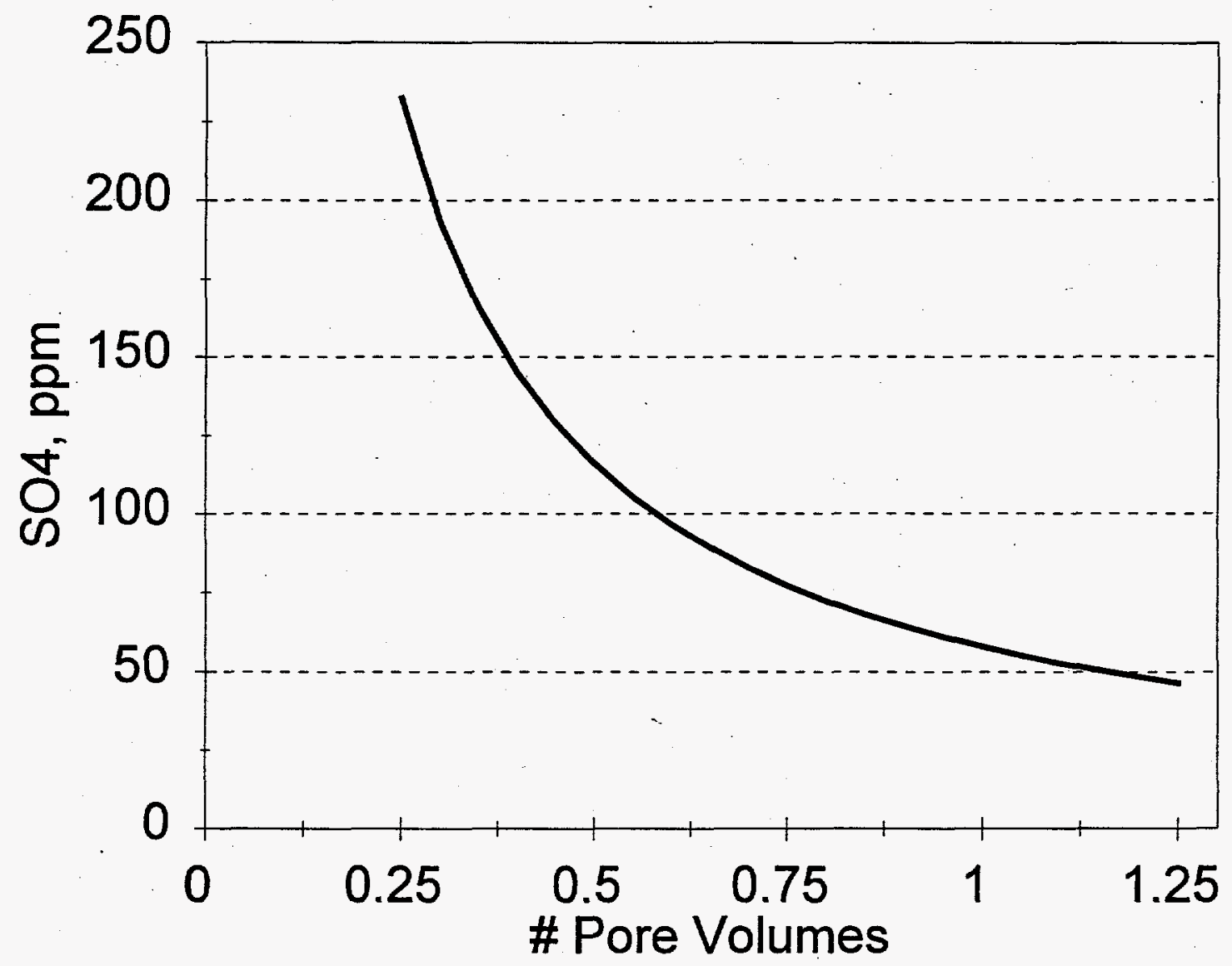

Figure 2.2. Variation in Sulfate Concentration Versus Number of Pore Volumes of Effluent Infiltrating the Vadose Zone 


\subsection{Variation in Aqueous Sulfate Concentration during Mineral Dissolution as a Function of Initial Effluent Composition}

The increase in sulfate concentration during dissolution of gypsum in water depends to some extent on initial solution chemistry. This section illustrates the magnitude of this effect by comparing gypsum solubility in pure water versus Columbia River water and in dilute $\mathrm{CaCl}_{2}$ solutions. In particular, this approach is relevant to assessing the potential upper limits for sulfate uptake of treated effluent infiltrating the vadose zone.

The MINTEQA2 geochemical equilibrium speciation model developed by EPA (Allison et al. 1991) was utilized to perform this exercise. This model is very versatile in this type of application because it permits the assessment of control of solution chemistry by solids such as gypsum, $\mathrm{CaSO}_{4} 2 \mathrm{H}_{2} \mathrm{O}$, and calcite, $\mathrm{CaCO}_{3}$.

The chemical composition of Columbia River water is presented in Table 3.1, which is an analysis of a composite sample collected several years ago (Thornton et al. 1995). Note that the sample was fairly dilute, with an ionic strength of about 0.002 and a pH of 8.0.

A summary of the modeling runs conducted with pure water $(\mathrm{pH}=7)$ and river water $(\mathrm{pH}=8.0)$ is presented in Table 3.2. Total calcium, sulfate, and carbonate concentrations in these solutions were determined when equilibrated with calcite alone, gypsum alone, and both calcite and gypsum simultaneously. Calcite and gypsum are minerals commonly present in soil and generally exert a control of solution chemistry in the vadose zone and groundwater systems.

The data in Table 3.2 illustrate that gypsum is more soluble than calcite. Both minerals dissolve to release calcium, while calcite also releases carbonate and gypsum also releases sulfate. Note the concentrations of calcium, sulfate, and carbonate present in water when both gypsum and calcite are present in excess; there is a slight increase in calcium and decreases in sulfate and carbonate relative to the cases where only the individual minerals are present. This may be attributed to the common ion effect $\left(\mathrm{Ca}^{2+}\right)$.

Table 3.2 indicates that calcium, sulfate, and carbonate are present in Columbia River water. If calcite is present in excess of its solubility in river water, the solution concentration of calcium and carbonate increases while sulfate remains unchanged. If gypsum is added in excess, calcium increases and sulfate increases. While carbonate remains unchanged in this case, modeling results indicate the solution is supersaturated with respect to calcite. The last case presented in Table 3.2 indicates the solution chemistry that would be expected if calcite precipitates so that the solution is saturated with respect to both gypsum and calcite. This case indicates that calcium and carbonate will decrease somewhat (in response to calcite precipitation), and sulfate will increase slightly (owing to the slight decrease in calcium concentration).

The results of these model runs indicate that minor variations in initial solution chemistry have a relatively moderate impact on final sulfate concentrations in the presence of excess calcite and gypsum. Thus, pure water acquired 0.009154 molal sulfate $(879 \mathrm{mg} / \mathrm{l})$, while river water acquired 0.01042 molal sulfate $(1001 \mathrm{mg} / \mathrm{l})$. The results suggest, however, that a solution that contains calcium without carbonate would tend to dissolve less gypsum and thus have somewhat lower sulfate concentrations at equilibrium. 
Table 3.1. Composition of Columbia River Water Composite Sample (B0BMM9 of Thornton et al. 1995)

\begin{tabular}{||l|c|r|r|r||}
\hline \multicolumn{1}{|c|}{ Constituent } & $\mathrm{mg} / \mathrm{L}$ & mmolal & meq/L & $\%$ total \\
\hline \hline $\mathrm{Na}$ & 2.4 & 0.10 & 0.10 & 7.78 \\
\hline $\mathrm{K}$ & 0.99 & 0.03 & 0.03 & 1.89 \\
\hline $\mathrm{Ca}$ & 17.3 & 0.43 & 0.86 & 64.37 \\
\hline $\mathrm{Mg}$ & 4.23 & 0.17 & 0.35 & 25.96 \\
\hline total cations & & & 1.34 & 100.00 \\
\hline $\mathrm{Cl}$ & 1.4 & 0.04 & 0.04 & 2.97 \\
\hline $\mathrm{SO}{ }_{4}$ & 10.5 & 0.11 & 0.22 & 16.46 \\
\hline $\mathrm{NO}_{3}$ & 0.26 & 0.00 & 0.00 & 0.32 \\
\hline $\mathrm{TIC}$ & 12.8 & 1.07 & 1.07 & 80.25 \\
\hline total anions & & & 1.33 & 100.00 \\
\hline $\mathrm{pH}$ (lab) & 8.0 & & & \\
\hline \hline
\end{tabular}

Table 3.2. Solubility of Gypsum and Calcite in Pure Water vs. Columbia River Water (total concentrations in molal, $\mathrm{pH}$ of water $=7, \mathrm{pH}$ of river water $=8.0$ )

\begin{tabular}{||l|l|l|l||}
\hline & $\mathrm{Ca}$ & $\mathrm{SO}_{4}{ }^{\circ}$ & $\mathrm{CO}_{3}$ \\
\hline \hline pure water & 0 & 0 & 0 \\
\hline water + calcite & 0.00386 & 0 & 0.00386 \\
\hline water + gypsum & 0.01008 & 0.01008 & 0 \\
\hline water + gypsum + calcite & 0.01153 & 0.00915 & 0.00238 \\
\hline Columbia River water & 0.00043 & 0.00011 & 0.00107 \\
\hline river + calcite & 0.00074 & 0.00011 & 0.00138 \\
\hline river + gypsum & 0.01038 & 0.01006 & 0.00107 \\
\hline river + gypsum + calcite & 0.00992 & 0.01042 & 0.00025 \\
\hline \hline
\end{tabular}


Quantitative evaluation of this effect can be assessed using MINTEQA2 if the initial solution chemistry is specified. Suppose, for example, that the initial solution chemistry consisted of dissolved $\mathrm{CaCl}_{2}$. Table 3.3 illustrates the relationship between sulfate concentration and initial $\mathrm{CaCl}_{2}$ concentration after equilibration occurs with calcite and gypsum. These results indicate that sulfate levels decrease as initial $\mathrm{CaCl}_{2}$ is increased. At an initial level of 0.1 molal $\mathrm{CaCl}_{2}$, for example, a final sulfate concentration of 0.004734 molal $(455 \mathrm{mg} / \mathrm{l})$ is predicted.

The results presented above illustrate that MINTEQA2 provides a means of predicting the maximum sulfate solution concentration after equilibration is attained with calcite and gypsum. This approach may be useful in predicting potential sulfate mobilization in the vadose zone associated with infiltration of treated effluent. To assess this effect, it is necessary only to specify the initial solution chemistry.

Table 3.3. Solubility of Gypsum and Calcite in Water as a Function of Initial $\mathrm{CaCl}_{2}$ Concentration (total concentrations in molal, $\mathrm{pH}=7.5$ )

\begin{tabular}{|l|c|c|c|c|}
\hline & $\mathrm{Ca}$ & $\mathrm{SO}_{4}$ & $\mathrm{CO}_{3}$ & $\mathrm{Cl}$ \\
\hline \hline $0.01 \mathrm{molal} \mathrm{CaCl}_{2}+$ gypsum + calcite & 0.0180 & 0.00754 & 0.000466 & 0.020 \\
\hline $0.02 \mathrm{molal} \mathrm{CaCl}_{2}+$ gypsum + calcite & 0.0270 & 0.00641 & 0.000352 & 0.040 \\
\hline $0.05 \mathrm{molal} \mathrm{CaCl}_{2}+$ gypsum + calcite & 0.0558 & 0.005576 & 0.000230 & 0.100 \\
\hline $0.10 \mathrm{molal} \mathrm{CaCl}_{2}+$ gypsum + calcite & 0.1049 & 0.00473 & 0.000160 & 0.200 \\
\hline
\end{tabular}




\subsection{Conclusions}

The origin of recent observed increases in sulfate levels of groundwater in the vicinity of the ETF disposal site can be attributed to dissolution of gypsum by water flowing through the vadose zone. This is supported by the observation that sulfate was found to be present in soils collected from the vadose zone during initial site characterization studies.

Soil sulfate concentrations obtained from soil analyses and leach tests performed during the characterization study suggest that an average value of about $10.6 \mathrm{ppm}$ sulfate is present in the vadose zone. The observed groundwater concentration of $190 \mathrm{mg} / \mathrm{L}$ sulfate could be achieved if 0.3 pore volumes of vadose zone water were to dissolve all of the gypsum present in vadose zone soils.

A maximum sulfate concentration of about $879 \mathrm{mg} / \mathrm{L}$ potentially could be achieved in the groundwater if it were assumed that water in the vadose zone were saturated with gypsum and calcite. It is unlikely that this level will be reached, however, since the concentration of sulfate present in the vadose zone is only about $10 \mathrm{ppm}$. It would be necessary for all of the sulfate in the vadose zone to be dissolved in only about 0.07 pore volumes of water to achieve gypsum saturation. If this were the case, we would expect to observe a relatively short period of very high sulfate levels (i.e., several weeks based on the observed breakthrough time of about a half year). It appears, rather, that sulfate achieved a maximum level of about $192 \mathrm{ppm}$ in well 699-48-77A on August 6, 1996, and subsequently started to decline after gypsum dissolution was completed. It is suggested that infiltration rates were high enough that the effluent did not completely equilibrate with gypsum in the vadose zone and thus did not attain sulfate levels that would be expected if saturation was achieved.

Geochemical modeling results suggest that variations in initial effluent chemistry have relatively moderate impact on sulfate concentrations in the presence of excess calcite and sulfate. A solution that contains calcium without carbonate would, however, tend to dissolve less gypsum in the vadose zone, and thus result in somewhat lower sulfate concentrations at equilibrium. Thus, a 0.1 molar $\mathrm{CaCl}_{2}$ solution could dissolve $455 \mathrm{mg} / \mathrm{L}$ of sulfate compared to $879 \mathrm{mg} / \mathrm{L}$ for pure water. 


\subsection{References}

Allison, J. D., D. S. Brown, and K. J. Novo-Gradac. 1991. MINTEQA2/PRODEFA2, A Geochemical Assessment Model for Environmental Systems: Version 3.0 User's Manual. EPA/600/3-91/021, Environmental Research Laboratory, U.S. Environmental Protection Agency, Athens, Georgia.

Davis, J. D., D. B. Barnett, C. J. Chou, and P. B. Freeman. 1995. Ground Water Screening Evaluation/ Monitoring Plan--200 Area Effluent Treatment Facility (Project C-018H). WHC-SD-C018H-PLN-004, Rev. 1, Westinghouse Hanford Company, Richland, Washington.

Freeze, R. A., and J. A. Cherry. 1979. Groundwater. Prentice-Hall Inc., Englewood Cliffs, New Jersey.

Garrels, R. M., and C. L. Christ. 1965. Solutions, Minerals, and Equilibria. Harper \& Row, New York.

Reidel, S. P., and E. C. Thornton. 1993. Characterization Report, C-018H Disposal Siting Evaluation. WHC-SD-C018H-RPT-001, Rev. 0, Westinghouse Hanford Company, Richland, Washington.

Thornton, E. C., J. E. Amonette, J. A. Olivier, and D. L. Huang. 1995. Speciation and Transport Characteristics of Chromium in the 100D/H Areas of the Hanford Site. WHC-SD-EN-TI-302, Rev. 0, Westinghouse Hanford Company, Richland, Washington. 
Appendix

Soil Column Leach Test Data 


\section{Appendix}

\section{Soil Column Leach Test Data}

\section{Test 2-1185}

In this test, a sample of soil collected from a depth of 0.5 to $1.0 \mathrm{ft}$ at the site was leached using deionized water. The mass of leachable sulfate recovered from the soil sample indicates that the soil contains at least $12.9 \mathrm{ppm}$.

NOTE: Leachate samples were weighed and converted to volume units based on the assumption that $1 \mathrm{~mL}=1$ gram. Sulfate was analyzed in the leachate samples by ion chromatography.

\begin{tabular}{|c|c|c|c|c||}
\hline Sample Number & $\begin{array}{c}\text { Leachate } \\
\text { Volume, } \mathrm{mL}\end{array}$ & $\begin{array}{c}\text { Number Column } \\
\text { Pore Volumes }\end{array}$ & $\mathrm{SO}_{4}, \mathrm{mg} / \mathrm{L}$ & $\mathrm{SO}_{4}, \mathrm{mg}$ \\
\hline \hline $2-1185-01$ & 290.52 & 0.00 to 0.79 & 47 & 13.65 \\
\hline $2-1185-02$ & 292.68 & 0.79 to 1.58 & 12 & 3.51 \\
\hline $2-1185-03$ & 443.11 & 1.58 to 2.79 & 4 & 1.77 \\
\hline $2-1185-04$ & 457.44 & 2.79 to 4.03 & 3 & 1.37 \\
\hline & & \multicolumn{3}{|c|}{ Total sulfate $=20.30 \mathrm{mg}$} \\
\hline
\end{tabular}

Sample $w t=1571.16 \mathrm{~g} \quad$ Column pore volume $=368.15 \mathrm{~mL}$

Concentration of total leachable sulfate in soil $=$

$$
\frac{\text { Total } \mathrm{SO}_{4}}{\text { sample wt }}=\frac{20.30 \mathrm{mg} \mathrm{SO}}{1571.16 \mathrm{~g} \text { soil }}=12.9 \frac{\mathrm{mg}}{\mathrm{kg}} \text { or } 12.9 \mathrm{ppm} \mathrm{SO}_{4}
$$




\section{Test 2-1186}

In this test, a sample of soil collected from a depth of 1.5 to $2.0 \mathrm{ft}$ at the site was leached using deionized water. The mass of leachable sulfate recovered from the soil sample indicates that the soil contains at least $5.9 \mathrm{ppm}$.

NOTE: Leachate samples were weighed and converted to volume units based on the assumption that $1 \mathrm{~mL}=1 \mathrm{gram}$. Sulfate was analyzed in the leachate samples by ion chromatography.

\begin{tabular}{||c|c|c|c|c||}
\hline Sample Number & $\begin{array}{c}\text { Leachate } \\
\text { Volume, } \mathrm{mL}\end{array}$ & $\begin{array}{c}\text { Number Column } \\
\text { Pore Volumes }\end{array}$ & $\mathrm{SO}_{4}, \mathrm{mg} / \mathrm{L}$ & $\mathrm{SO}_{4}, \mathrm{mg}$ \\
\hline \hline $2-1186-01$ & 307.31 & 0.00 to 0.91 & 13 & 4.00 \\
\hline $2-1186-02$ & 615.13 & 0.191 to 1.82 & 4 & 2.46 \\
\hline $2-1186-03$ & 454.46 & 1.82 to 3.17 & 3 & 1.36 \\
\hline $2-1186-04$ & 460.14 & 3.17 to 4.54 & 3 & 1.38 \\
\hline
\end{tabular}

Sample wt $=1547.79 \mathrm{~g}$

Column pore volume $=337.13 \mathrm{~mL}$

Concentration of total leachable sulfate in soil $=$

$$
\frac{\text { Total } \mathrm{SO}_{4}}{\text { sample wt }}=\frac{9.20 \mathrm{mg} \mathrm{SO}}{1547.79 \mathrm{~g} \text { soil }}=5.9 \frac{\mathrm{mg}}{\mathrm{kg}} \text { or } 5.9 \mathrm{ppm} \mathrm{SO}_{4}
$$




\section{Test 2-1188}

In this test, a sample of soil collected from a depth of 26.0 to $26.5 \mathrm{ft}$ at the site was leached using deionized water. The mass of leachable sulfate recovered from the soil sample indicates that the soil contains at least $4.4 \mathrm{ppm}$.

NOTE: Leachate samples were weighed and converted to volume units based on the assumption that $1 \mathrm{~mL}=1 \mathrm{gram}$. Sulfate was analyzed in the leachate samples by ion chromatography.

\begin{tabular}{|c|c|c|c|c||}
\hline Sample Number & $\begin{array}{c}\text { Leachate } \\
\text { Volume, } \mathrm{mL}\end{array}$ & $\begin{array}{c}\text { Number Column } \\
\text { Pore Volumes }\end{array}$ & $\mathrm{SO}_{4}, \mathrm{mg} / \mathrm{L}$ & $\mathrm{SO}_{4}, \mathrm{mg}$ \\
\hline \hline $2-1188-01$ & 278.82 & 0.00 to 0.73 & 18 & 5.02 \\
\hline $2-1188-02$ & 309.99 & 0.73 to 1.53 & 4 & 1.24 \\
\hline $2-1188-03$ & 447.54 & 1.53 to 2.70 & 3 & 1.34 \\
\hline $2-1188-04$ & 450.26 & 2.70 to 3.87 & 2 & 0.90 \\
\hline
\end{tabular}

Sample $w t=1949.55 \mathrm{~g}$

Column pore volume $=383.76 \mathrm{~mL}$

Concentration of total leachable sulfate in soil $=$

$$
\frac{\text { Total } \mathrm{SO}_{4}}{\text { sample wt }}=\frac{8.50 \mathrm{mg} \mathrm{SO}}{1949.55 \mathrm{~g} \mathrm{soil}}=4.4 \frac{\mathrm{mg}}{\mathrm{kg}} \text { or } 4.4 \mathrm{ppm} \mathrm{SO}_{4}
$$




\section{Test 2-1190}

In this test, a sample of soil collected from a depth of 34.8 to $35.3 \mathrm{ft}$ at the site was leached using deionized water. The mass of leachable sulfate recovered from the soil sample indicates that the soil contains at least $4.3 \mathrm{ppm}$.

NOTE: Leachate samples were weighed and converted to volume units based on the assumption that $1 \mathrm{~mL}=1$ gram. Sulfate was analyzed in the leachate samples by ion chromatography.

\begin{tabular}{||c|c|c|c|c||}
\hline Sample Number & $\begin{array}{c}\text { Leachate } \\
\text { Volume, } \mathrm{mL}\end{array}$ & $\begin{array}{c}\text { Number Column } \\
\text { Pore Volumes }\end{array}$ & $\mathrm{SO}_{4}, \mathrm{mg} / \mathrm{L}$ & $\mathrm{SO}_{4}, \mathrm{mg}$ \\
\hline \hline $2-1190-01$ & 252.93 & 0.00 to 0.68 & 17 & 4.30 \\
\hline $2-1190-02$ & 298.85 & 0.68 to 1.48 & 8 & 2.39 \\
\hline $2-1190-03$ & 460.42 & 1.48 to 2.72 & 4 & 1.84 \\
\hline $2-1190-04$ & 456.47 & 2.72 to 3.95 & 3 & 1.37 \\
\hline & \multicolumn{3}{|c}{ Total sulfate $=9.90 \mathrm{mg}$} \\
\hline
\end{tabular}

Sample wt $=2313.78 \mathrm{~g}$ Column pore volume $=372.07 \mathrm{~mL}$

Concentration of total leachable sulfate in soil $=$

$$
\frac{\text { Total } \mathrm{SO}_{4}}{\text { sample wt }}=\frac{9.90 \mathrm{mg} \mathrm{\textrm {SO } _ { 4 }}}{2313.78 \mathrm{~g} \text { soil }}=4.3 \frac{\mathrm{mg}}{\mathrm{kg}} \text { or } 4.3 \mathrm{ppm} \mathrm{SO}_{4}
$$




\section{Test 2-1192}

In this test, a sample of soil collected from a depth of 43.1 to $43.6 \mathrm{ft}$ at the site was leached using deionized water. The mass of leachable sulfate recovered from the soil sample indicates that the soil contains at least $11.7 \mathrm{ppm}$.

NOTE: Leachate samples were weighed and converted to volume units based on the assumption that $1 \mathrm{~mL}=1 \mathrm{gram}$. Sulfate was analyzed in the leachate samples by ion chromatography.

\begin{tabular}{||c|c|c|c|c|}
\hline Sample Number & $\begin{array}{c}\text { Leachate } \\
\text { Volume, } \mathrm{mL}\end{array}$ & $\begin{array}{c}\text { Number Column } \\
\text { Pore Volumes }\end{array}$ & $\mathrm{SO}_{4}, \mathrm{mg} / \mathrm{L}$ & $\mathrm{SO}_{4}, \mathrm{mg}$ \\
\hline \hline $2-1192-01$ & 237.98 & 0.00 to 0.64 & 59 & 14.04 \\
\hline $2-1192-02$ & 267.69 & 0.64 to 1.37 & 15 & 4.02 \\
\hline $2-1192-03$ & 403.97 & 1.37 to 2.46 & 6 & 2.42 \\
\hline $2-1192-04$ & 455.86 & 2.46 to 3.69 & 4 & 1.82 \\
\hline & \multicolumn{3}{|c|}{ Total sulfate $=22.30 \mathrm{mg}$} \\
\hline
\end{tabular}

Sample $w \mathrm{t}=1906.32 \mathrm{~g} \quad$ Column pore volume $=370.01 \mathrm{~mL}$

Concentration of total leachable sulfate in soil $=$

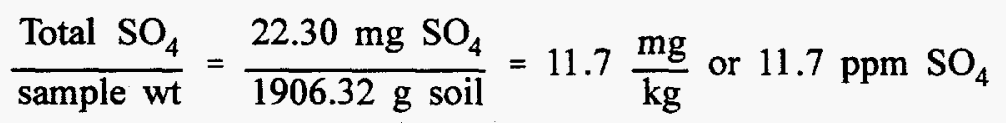




\section{Test 2-1194}

In this test, a sample of soil collected from a depth of 57.2 to $57.7 \mathrm{ft}$ at the site was leached using deionized water. The mass of leachable sulfate recovered from the soil sample indicates that the soil contains at least $6.5 \mathrm{ppm}$.

NOTE: Leachate samples were weighed and converted to volume units based on the assumption that $1 \mathrm{~mL}=1$ gram. Sulfate was analyzed in the leachate samples by ion chromatography.

\begin{tabular}{||c|c|c|c|c|}
\hline Sample Number & $\begin{array}{c}\text { Leachate } \\
\text { Volume, } \mathrm{mL}\end{array}$ & $\begin{array}{c}\text { Number Column } \\
\text { Pore Volumes }\end{array}$ & $\mathrm{SO}_{4}, \mathrm{mg} / \mathrm{L}$ & $\mathrm{SO}_{4}, \mathrm{mg}$ \\
\hline \hline $2-1194-01$ & 223.92 & 0.00 to 0.58 & 41 & 9.18 \\
\hline $2-1194-02$ & 270.13 & 0.58 to 1.29 & 6 & 1.62 \\
\hline $2-1194-03$ & 410.65 & 1.29 to 2.36 & 3 & 1.23 \\
\hline $2-1194-03$ & 456.00 & 2.36 to 3.55 & 3 & 1.37 \\
\hline
\end{tabular}

Sample $\mathrm{wt}=2067.12 \mathrm{~g} \quad$ Column pore volume $=383.74 \mathrm{~mL}$

Concentration of total leachable sulfate in soil $=$

$\frac{\text { Total } \mathrm{SO}_{4}}{\text { sample wt }}=\frac{13.40 \mathrm{mg} \mathrm{SO}}{2067.12 \mathrm{~g} \mathrm{soil}}=6.5 \frac{\mathrm{mg}}{\mathrm{kg}}$ or $6.5 \mathrm{ppm} \mathrm{SO}_{4}$ 


\section{Test 2-1195}

In this test, a sample of soil collected from a depth of 57.7 to $58.2 \mathrm{ft}$ at the site was leached using deionized water. The mass of leachable sulfate recovered from the soil sample indicates that the soil contains at least $4.8 \mathrm{ppm}$.

NOTE: Leachate samples were weighed and converted to volume units based on the assumption that $1 \mathrm{~mL}=1 \mathrm{gram}$. Sulfate was analyzed in the leachate samples by ion chromatography.

\begin{tabular}{||c|c|c|c|c||}
\hline Sample Number & $\begin{array}{c}\text { Leachate } \\
\text { Volume, } \mathrm{mL}\end{array}$ & $\begin{array}{c}\text { Number Column } \\
\text { Pore Volumes }\end{array}$ & $\mathrm{SO}_{4}, \mathrm{mg} / \mathrm{L}$ & $\mathrm{SO}_{4}, \mathrm{mg}$ \\
\hline \hline $2-1195-01$ & 243.04 & 0.00 to 0.63 & 22 & 5.35 \\
\hline $2-1195-02$ & 300.35 & 0.63 to 1.42 & 4 & 1.20 \\
\hline $2-1195-03$ & 465.04 & 1.42 to 2.63 & 3 & 1.40 \\
\hline $2-1195-04$ & 463.71 & 2.63 to 3.84 & 2 & 0.93 \\
\hline
\end{tabular}

Sample wt $=1861.71 \mathrm{~g}$

Column pore volume $=382.96 \mathrm{~mL}$

Concentration of total leachable sulfate in soil $=$

$$
\frac{\text { Total } \mathrm{SO}_{4}}{\text { sample wt }}=\frac{8.88 \mathrm{mg} \mathrm{SO}}{1861.71 \mathrm{~g} \mathrm{soil}}=4.8 \frac{\mathrm{mg}}{\mathrm{kg}} \text { or } 4.8 \mathrm{ppm} \mathrm{SO}_{4}
$$


Test 2-1433

In this test, a sample of soil collected from a depth of 68.0 to $68.5 \mathrm{ft}$ at the site was leached using deionized water. The mass of leachable sulfate recovered from the soil sample indicates that the soil contains at least $3.4 \mathrm{ppm}$.

NOTE: Leachate samples were weighed and converted to volume units based on the assumption that $1 \mathrm{~mL}=1$ gram. Sulfate was analyzed in the leachate samples by ion chromatography.

\begin{tabular}{||c|c|c|c|c||}
\hline Sample Number & $\begin{array}{c}\text { Leachate } \\
\text { Volume, } \mathrm{mL}\end{array}$ & $\begin{array}{c}\text { Number Column } \\
\text { Pore Volumes }\end{array}$ & $\mathrm{SO}_{4}, \mathrm{mg} / \mathrm{L}$ & $\mathrm{SO}_{4}, \mathrm{mg}$ \\
\hline \hline $2-1433-01$ & 288.72 & 0.00 to 0.80 & 14 & 4.04 \\
\hline $2-1433-02$ & 299.56 & 0.80 to 1.64 & 3 & 0.90 \\
\hline $2-1433-03$ & 458.02 & 1.64 to 2.91 & 3 & 1.37 \\
\hline $2-1433-04$ & 474.40 & 2.91 to 4.23 & 2 & 0.95 \\
\hline
\end{tabular}

Sample wt $=2151.32 \mathrm{~g}$

Column pore volume $=359.56 \mathrm{~mL}$

Concentration of total leachable sulfate in soil $=$

$$
\frac{\text { Total } \mathrm{SO}_{4}}{\text { sample wt }}=\frac{7.26 \mathrm{mg} \mathrm{SO}}{2151.32 \mathrm{~g} \text { soil }}=3.4 \frac{\mathrm{mg}}{\mathrm{kg}} \text { or } 3.4 \mathrm{ppm} \mathrm{SO}_{4}
$$




\section{Distribution}

No. of

Copies

OFFSITE

2 DOE/Office of Scientific and Technical Information

\section{ONSITE}

2 Rust Federal Services of Hanford, Inc.

D. L. Flyckt

S6-71

P. C. Mohondro

S6-72
No. of

Copies

8 Pacific Northwest National Laboratory

D. B. Barnett

K6-81

E. C. Thornton (7)

K6-96

Information Release Office (7) 